\title{
Of Grim Witches and Showy Lady-Devils: Wealthy Women in Literature and Film
}

\section{ABSTRACT}

Imagining super rich women in the real and fictional world has long been a struggle. Those few depictions that do exist are scattered across time periods and literary genres, reflecting the legal restrictions that, at different points in time, would not allow women to accumulate assets independent of the patriarchal forces in their lives. The scarcity of extremely wealthy women in literature and film is confirmed by Forbes magazine's list of the fifteen richest fictional characters that features forty different fictional men and only nine women, with never more than two female characters nominated in a single year.

This article explores the depiction of three exceptionally wealthy women: Cruella de Vil in The Hundred and One Dalmatians (1956) by Dodie Smith, Miss Havisham in Great Expectations (1861) by Charles Dickens, and the figure of the stepmother in various adaptations of "Cinderella." I demonstrate how the protagonists' wealth allows them to manipulate others and disconnect themselves from patriarchal and societal expectations. Further, I argue that these affluent antagonists are "rogued" by their respective narratives, highlighting their perceived anti-feminine and emasculating behaviour resulting in a mode of narration that greedily gazes at and shames their appearances and supposed unattractiveness. While this genealogy of rich rogues reiterates the narrow scope of imagining wealthy women on the page and on the screen, there are moments in the narratives that disrupt stereotypical depictions of these wealthy characters who defy the labels imposed on them.

Keywords: wealthy women, rich rogues, Cinderella, Miss Havisham, Cruella de Vil. 
“'What a strange name de Vil is,' said Mr Dearly. 'If you put the two words together, they make devil. Perhaps Cruella's a lady-devil" (Smith 14). The lady-devil that features so prominently in Dodie Smith's The Hundred and One Dalmatians has become the embodiment of the villainous wealthy woman, so wealthy in fact that she is thought to be one of the nine richest female characters ever created. This article investigates female characters who are not just wealthy but possess such enormous riches that they are considered to be among the wealthiest people imagined in literature and film. Forbes magazine have published a list detailing the fifteen richest fictional characters since 2002. What is compelling about these "Fictional 15 ," as they are called by the magazine, is that over the years the list has featured 40 different fictional men but only nine women and no more than two female characters were nominated in a single year. ${ }^{1}$ Similarly, only one woman is among the wealthiest fifteen people in 2019 (Dolan and Kroll). While there is an abundance of literature concerned with women and wealth from Antiquity through the Middle Ages to studies of the gender-related financial difficulties women face nowadays, very little attention has been paid thus far to representations of extremely wealthy women in literature and film. One might partly attribute this to their scarce appearances which see them scattered across multiple centuries and several genres, both on the page and on the screen. ${ }^{2}$

1 In order for a character to qualify for the Forbes "Fictional 15," they have to be an authored fictional creation, a rule which seeks to exclude mythological, folkloric and magical characters, and most importantly, she or he must be known, both within their fictional world and by their audience, for being rich. In a desperate attempt to create some sort of gender balance, the Tooth Fairy, whose gender remains disputable, was added to the list venturing into (anglophone) folkloric territory. Once a character's pronounced wealth is established, their assets are based on an analysis of their source of income and are valued against known real-world commodity and share price movements (Ewalt). Through this mode of assessment the following women (in order of appearance) can be found on the Forbes lists over the last ten years: Cruella de Vil (The Hundred and One Dalmatians by Dodie Smith), Jo Bennett (TV series The Office), Lady Tremaine ("Cinderella"), Lara Croft (video game Tomb Raider), Lisbeth Salander (The Girl With The Dragon Tattoo by Stieg Larsson), Lucille Bluth (TV series Arrested Development), Mom (TV series Futurama), Princess Toadstool (Super Mario Bros. video games), and the Tooth Fairy.

2 The texts and film adaptations discussed in this article are naturally influenced by and reflect the historical circumstances of their times that would allow women access to wealth only to varying degrees. These legal and societal limitations also had an impact on how wealthy women were imagined at different points in time and across different parts of the world. An excellent more comprehensive overview on women and wealth is provided, for example, 
The "Forbes 15 " and the lack of female contestants is merely a symptom of a much more fundamental problem which is "a small pool of candidates. For some reason authors, screenwriters, directors, and comic book artists haven't been creating many ultrarich female characters" (Howard). What transpires thus from the "Fictional 15" and its real-world equivalent is that wealth is not just a gendered issue but one that is even more deeply racialized. The distribution of wealth, in the real and fictional realm, is deeply symptomatic of a system that not only privileges whiteness but also constantly reproduces it. All fictional women found on the Forbes list, and the three characters discussed in this article, are white women who benefit from their whiteness. While there is no doubt that from a gendered perspective, women find themselves in an infinitely more disadvantaged position in comparison to their male counterparts in all walks of financial life, white women still stand an infinitely better chance to acquire wealth overall, if predominantly through their connections to rich white men. This still holds true in 2019 when not a single non-white billionaire of either sex can be found among the world's ten richest people.

In this article, I want to explore the depiction of three exceptionally wealthy female rogues whose (male) source of wealth is no longer a focal point in the narrative: Lady Tremaine in various adaptations of "Cinderella" (1698, 1812, 1950, 2015), Miss Havisham in Great Expectations (1861) by Charles Dickens and its two TV adaptations (2011, 2012), and Cruella de Vil based on Dodie Smith's The Hundred and One Dalmatians which was later adapted by Disney $(1961,1996)$. The women's perceived roguery seemingly manifests itself in their mere existence, as their wealth allows them to creatively manipulate others and disconnect themselves from male and societal expectations to a large extent. This perceived anti-feminine and emasculating behaviour is met with anger and disdain by other characters, and the wealthy women's attributed roles as villains become central to their depiction, resulting in a mode of narration that greedily gazes at and shames their appearances. While this genealogy of rich female rogues partly reiterates the narrow scope of imagining wealthy women on the page and on the screen, there are moments in these narratives that disrupt stereotypical depictions of these wealthy characters who defy the labels imposed on them and instead lend themselves to a protofeminist reading of female prosperity. While Cruella de Vil and Lady Tremaine make multiple appearances in the "Fictional 15," one of the most

by Women and their Money 1700-1950: Essays on Women and Finance (2009), edited by Anne Laurence, Josephine Maltby and Janette Rutterford, containing particularly relevant contributions for the historical circumstances surrounding all three texts. 
widely recognized prosperous literary figures, Miss Havisham, narrowly misses the list every time, since there is doubt whether "she really [is] the Victorian equivalent of a billionaire" (Noer). While the selection of texts and protagonists is disparate, covering an array of genres and time periods, it also reveals an astonishingly similar narrative treatment of wealthy women. Their relegation to the realm of children's literature and folk talks, for example, reiterates their inconceivable existence, be this for the historical circumstances that, in the Western world, would often deny women the right own of property or the patriarchal structures that would bar women from taking up roles of power.

This article focuses on the ways in which the protagonists are "rogued" by their respective texts rather than being intentional rogues. All narratives discussed, except Dodie Smith's, were penned by men, Great Expectations and The Hundred and One Dalmatians also feature male narrative voices, and the film adaptations were all directed by men. I thus read the characters as projected rogues since it is the texts' masculinist disposition that exasperates the women's villainous, untrustworthy, and undesirable qualities brought about by their exceptional wealth that sees them freed from some of the societal pressures of their times. Throughout this article, I follow Kirsten Backstrom's understanding of the rogue as a woman outside patriarchal expectations. She explains that

$[\mathrm{w}]$ hen men determine the standard . . . any independent woman is a rogue. Any feminist, any lesbian, any woman of color is some sort of rogue.... A rogue is a woman who challenges assumptions. Any rigid definition is dangerous. If you can't change, you won't survive. ... Her uniqueness arises from contradictions; she is not always right. Her motives are selfish and selfless. She is more than the sum of her parts.

(Backstrom qtd. in Overall 54)

It is the room that is given to ambiguity that is particularly striking in this passage, an ambiguity that I argue is purposefully obscured in the rather one-sided depiction of the affluent female antagonists. As will be illustrated in the subsequent discussion, there are recurring narrative patterns in the texts and film adaptations "rogueing" the wealthy women along three major axes.

Firstly, the prosperous protagonists subvert the patriarchal structures of marriage which they manage to bend to their own advantage or substitute with a life of self-determined spinsterhood. This conscious rejection is met with an almost obsessive fixation on their bodies and faces, highlighting their masculine and unmotherly features in an attempt to undermine their independence and present them as undesirable women. 
While Cruella's husband plays a very minor role in Smith's original novel, her marital status is completely erased in the subsequent two Disney film adaptations, Miss Havisham has remained unmarried all her life after an unlucky almost-wedding, and Lady Tremaine is widowed at least once and even after her second marriage she is imagined alone. In a brief exploration of wealthy characters, Daphne Merkin eventually comes to the conclusion that " $[w]$ hat is absent, it seems to me, from our sense of the wealthy, is an understanding of their flesh-and-bloodness." It is telling that this conclusion is reached after only male characters were taken into consideration, given that the three wealthy women studied in this article are unable to escape the narrative infatuation with their "flesh-and-bloodness."

Secondly, the narratives emphasize the dichotomy between income and wealth and therefore between activity and passivity. "Wealth and income are sometimes related," Mariko Lin Chang points out, "but they are not the same [since] income refers to the amount of money received by an individual or household during a specific period of time [whereas] wealth, or net worth, refers to the total value of [a person's] financial and nonfinancial assets minus debts" (3). In the texts, the protagonists' source of income remains largely obscured, leaving these rich women to occupy the position of passive owners of vast fortunes instead of showing them either managing their assets or acquiring them through hard and skilled labour. This reflects of course the legal limitations that women, such as Lady Tremaine and Miss Havisham, faced in $18^{\text {th }}$-and $19^{\text {th }}$-century England that made it almost impossible for them to accumulate assets outside of patriarchal relations. Equally wealthy men with similarly acquired riches are granted a much more nuanced description in the narratives, underscoring the historical implication that women are rich rather than capable of acquiring wealth through skilled labour.

Finally, the narratives feature at least one figure of the anti-rogue: a female character who incarnates the ideal image of a woman, within the text and its time, and serves to not only amplify the rich female protagonists' womanly shortcomings but also to incur their wrath, confirming their witch-like and irrational nature.

One of those wrathful characters features prominently in the "Cinderella" tale's version that is most commonly known today-the good-natured Cinderella who is abused by a cold-hearted stepmother and marries the prince against all odds-dates back to a French tale written by Charles Perrault in 1698, although the story itself has a long history with the earliest known version dating back to $9^{\text {th }}$-century China. Even in that earliest configuration, the stepmother is so cruel that she eats the pet fish Cinderella sought comfort in after the passing of both her parents (Cullen 57-58). Through the centuries, the figure of the evil stepmother 
has gained momentum; she has become meaner, more manipulative, richer, and most importantly, she has gained significant narrative space in the Western version of the fairy tale since the $18^{\text {th }}$ century. Perrault's rendering of "Cinderella" also formed the basis for the 1950 cinematic Disney adaptation that would "eclipse" all other versions of the tale (Cullen 57) and in many ways continues the Victorian tradition of using fairy tales to pursue pedagogical goals by promoting conservative, heteronormative and anti-feminist notions of family life, relationships and women's rights a frequent site of criticism (Byrne and McQuillan 1). While the unnamed stepmother does not feature prominently in Perrault's version or the later, also immensely popular, retelling by the Grimm Brothers, she functions as the archetype of the jealous woman who sets Cinderella up for a life of misery she eventually triumphantly manages to escape. The stepmother's quiet overshadowing of the tale results in a disembodied version of the wealthy matriarch ultimately providing Disney with the opportunity to reinvent the character as the raging rogue.

Perrault opens his tale with the introduction of an unnamed widowed gentleman who took "the proudest and haughtiest woman who had ever been seen" (130) as his second wife. The reader does not learn about her background, but it can be assumed that by the time of her second marriage to Cinderella's wealthy father, she must have accumulated significant assets. After securing the status of wife, the stepmother "gave free rein to her temper" (Perrault 130), revealing her deceitful nature which is portrayed to stem from a deep hatred of Cinderella who is said to make her and her daughters look "even more detestable" (Perrault 130) in comparison. The stepmother's rage is one of the most direct expressions of disdain at the character of the anti-rogue and the ideal of female submissiveness. The stepmother is absent in the narrative thereafter but remains indirectly present since her two daughters "resembled her in everything" (Perrault 130). While their physical attributes are never addressed, the narrative juxtaposes Cinderella's rundown exterior and her kind and gentle disposition with the sisters' lavish dresses and rotten character. With the arrival of "Aschenputtel" by the Grimm Brothers in 1812, the figure of the stepmother becomes increasingly brutalized, referring to her stepdaughter as "this terrible and useless thing" (69), and later encouraging her own daughters to mutilate their bodies by cutting off parts of their feet in order to fit the glass slipper. Similarly to Perrault's version, the two sisters are described as having "beautiful features but proud, nasty, and wicked hearts” (Grimm Brothers 69) and the juxtaposition of the good and obedient anti-rogue Cinderella and later on the Fairy Godmother with the unmotherly matriarch takes precedent once more. 
Disney's twelfth animated film is based on Perrault's "Cendrillon” but in many ways channels the much more forceful nature of the stepmother as imagined by the Grimm Brothers, paving the way for the wealthy Lady Tremaine, "a woman of good family," who has since become an iconic representation of the evil stepmother figure in modern times. Lady Tremaine is a cold, confident and calculating woman who seems fully aware of the patriarchal mechanisms operating within her society and has learned to manipulate them in her favour. Widowed twice in the film, her only objectives are to further extend her power and grow her wealth, which she hopes to achieve by strategically marrying off her daughters. In this quest, Cinderella presents an obstacle since her hyperfeminine presence highlights the Tremaine women's more masculine and awkward features that are exaggerated in the film to a breaking point. In her article on transgendered villains in Disney films, Amanda Putnam asserts that "dramatic and daring, the villains often outperform their heterosexual rivals, setting up a transparent comparison between 'normative' and 'deviant' gendered behaviors, but also connecting the villains' transgenderism with sarcasm, selfishness, cruelty, greed and brutality" (151). She further comments that Lady Tremaine especially is "distanced from femininity" underlined by her facial features whose sharp edges alongside her grey skin colour and menacing eyes should communicate her unmotherly, and thus unfeminine, tendencies which are further highlighted by her fierce rule over the three young women in her household for whom she displays little empathy. While Lady Tremaine does not use physical violence, the pressure she puts on those around her is significant. The gap, however, between Cinderella as the anti-rogue and Lady Tremaine and her "flat-chested and boyish" (Putnam 153) daughters as the unsexed and unattractive rich heiresses becomes the defining narrative focus also in the Disney film. The former's ultra-feminine features are soft and correspond with traditional Western ideas of beauty and throughout the film Cinderella conducts herself gracefully without ever complaining, stoically accepting her fate regardless of the humiliations she endures daily. Lady Tremaine, in contrast, embodies a type of woman whose background is just as privileged as Cinderella's but who, instead of stoic acceptance and complicity, takes on the role of the patriarchal force. In line with Disney's streamlined portrayal of the heterosexual, hyperfeminized and obedient woman that lasted well into the 1990s, Cinderella is eventually rewarded for her conformist behaviour by entering into a marriage with the prince, ultimately fulfilling her destiny of a life of privilege. The 2015 live-action remake, starring Cate Blanchett as Lady Tremaine, shows a significant modernization in the way in which the character is portrayed. Even though she still embodies the abusive and power hungry socialite, she has lost her masculine features and is instead depicted 
as a woman of great beauty who is also exceptionally well-dressed and teaches her daughters that "all men are fools." Overall, however, Disney's Cinderella poses as a rags to riches story, creating an artificial dichotomy between the apparently poor, hard-working and cheerful Cinderella and the rich and cruel Lady Tremaine who does not seem to display any significant skills. Her rogue behaviour is portrayed as her main occupation, but overall it is attempted to depict her as a passive character: she is hardly ever shown running her household or managing her fortune, in fact, we encounter her frequently still in bed when Cinderella is serving her breakfast, thus reiterating the stereotypical passivity of the female recipient of wealth. The woman who has learned to bend the pervasive patriarchal structures in her favour is ultimately punished for her unruly and unwomanly behaviour when she is humiliated by her stepdaughter's ultimate success, paving the way also for Great Expectations and The Hundred and One Dalmatians that see their rich rogues disciplined at the end.

Miss Havisham, Charles Dickens's famous unmotherly rich spinster, also abuses the young people in her care and finds herself frequently "filed away under 'weird spinsters: various' [and] retrieve [d...] periodically in her yellowed bridal dress, the light of day shut out from the decaying feast chamber in which she sits. If she is not sitting when we conjure her up, she is burning; a flaming figure" (Thornton 79). Miss Havisham's ultimate painful death to which is alluded here, evokes, of course, the ageold story of the unruly woman being burned at the stake. Throughout the narrative, parallels are drawn between the prosperous protagonist and her stereotypically disorderly physical appearance and her unkempt hair which makes her appear like "the Witch" (Dickens 77) of her rundown estate in the eyes of the orphan Pip who becomes the playmate for Miss Havisham's adopted daughter Estelle. It is relatively late in the novel that the reader is informed about Miss Havisham's past: one learns about her spoilt childhood, her very rich and very proud father (Dickens 164), the jealous half-brother who felt himself tricked out of a large part of his inheritance and set his sister up with a man who left her on their wedding day. Miss Havisham had never been able to move on from the traumatic events of that day, leading her to remain in her wedding dress, a sight so peculiar that Pip scrutinizes her appearance during their first encounter:

She was dressed in rich materials,_-satins, and lace, and silks,-all of white. Her shoes were white. And she had a long white veil dependent from her hair, and she had bridal flowers in her hair, but her hair was white. Some bright jewels sparkled on her neck and on her hands, and some other jewels lay sparkling on the table. Dresses, less splendid than the dress she wore, and half-packed trunks, were scattered about. She had not quite 
finished dressing, for she had but one shoe on,- - the other was on the table near her hand,- - her veil was but half arranged, her watch and chain were not put on, and some lace for her bosom lay with those trinkets, and with her handkerchief, and gloves, and some flowers, and a Prayer-Book all confusedly heaped about the looking-glass. (Dickens 52)

The attention that is given to Miss Havisham's body-from head to toe-becomes a dominant focus in Pip's narrative and thus also how the reader is made to perceive her character. Fully aware of her memorable appearance, Miss Havisham keeps checking her image in the looking-glass which has been interpreted as a sign of her loss of identity (Ciugureanu 353), a notion I disagree with. I read her continuous inspection of her image in the mirror, as well as her firm invitation for others to look at her too, as a crucial moment of transgression: Miss Havisham is neither afraid of nor embarrassed by her ageing face. Her body is a testament to her endurance and the hardship and isolation she has faced throughout her life. Like the two other characters studied in this article, Miss Havisham exhibits typical anti-feminine traits and as "the Witch of the place" (Dickens 77) she is depicted as cold-hearted, unpleasant and lacking substantial maternal instincts. Her unruliness is shown in a general rejection of exchanging pleasantries where she refuses to emanate the womanly warmth and kindness that have so often been denied to her by others, pushing against "the dangerously self-sacrificing model of Victorian womanhood" (Levine 105). She takes particularly unkindly to flattery, especially when it relates to her looks since she rejects the notion of needing to look desirable for the sake of others: "I do not [look well]. I am yellow skin and bone" (Dickens 78) and when she is asked for a favour she immediately declines, asking "Who am I.... Who am I, for God's sake, that I should be kind?" (Dickens 329). Dickens's novel, similarly to Dodie Smith's narrative, relies on the adolescent Pip as narrator and provides a projection of Miss Havisham through his eyes and at times his “'topsy-turvy vision' leads him to read the world in reverse" (Levine 103). While one can definitely find evidence of the male gaze that is ever so present in this Victorian text, it also becomes evident that the relationship between Miss Havisham and her spectators is reciprocal at times. Like Cruella de Vil and Lady Tremaine, Miss Havisham is used to the attention that is paid to her and the power her wealth grants her over others. While she is acutely aware of and disturbed by her visitors' curious gazes, she has already picked out the table "where [she] will be laid when [she is] dead" and everyone "shall come and look at [her]" (Dickens 77). Even though she has chosen a life of solitude, living the life of a recluse at her estate, she refuses to conceal the pain she has endured in the past or accept people's voyeuristic curiosity. 
Miss Havisham's atypical behaviour is further highlighted in the novel, just as it is in The Hundred and One Dalmatians and "Cinderella," with the introduction of the figure of the anti-rogue. In Great Expectations, we are confronted with a "typology of pure and impure women" (Hartog 248) that serves to underscore Miss Havisham's, Mrs Joe's and Estella's predatory behaviour that translates as them lacking "the capacity to love [and] becom[ing] destructive to themselves and men" which is why "they must be held firmly, even violently in check" (Hartog 248). Great Expectation's anti-rogue Biddy is described as "the most obliging of girls" (Dickens 66), "never insulting, or capricious" (Dickens 57), as well as "smart" and similarly, the reader witnesses another anti-rogue, Clara, who is "so natural and winning ... loving, and innocent ... gentle ... needing protecting" while remaining "modest" (Dickens 255). The anti-rogues" exemplary behaviour is rewarded with marriage whereas Miss Havisham is completely abandoned and annihilated by fire.

Much of Dickensian criticism concerned with the study of Great Expectations has focused on the parallels between Miss Havisham's ageing and failing body and the failing economy at the time. Susan Walsh, for example, notes that " $[\mathrm{h}]$ er history as an unmarried heiress conjures up midcentury debates about women's changing roles and financial commitments" while also upholding a certain Victorian "conservationalist nostalgia” (74) for which Donald E. Hall sees Dickens's “defenses regarding effective feminist challenges to patriarchy ... paying close attention to changing social circumstances allowing gender roles to metamorphose" (185). Along those lines, Miss Havisham, a rich and independent self-determined spinster, is not allowed to succeed but "illustrates a significant sort of female failure" who "refuses to sponsor her male relatives, . . . blocks her financial capital from circulating within the proper channels of investment and trade, thus rendering it economically barren" (Walsh 90). It is above all Miss Havisham's wealth that allows her to choose that life of perceived failure without having to worry about suffering consequences that could seriously impact her chances of survival-for her, money is the cause for her position as a rogue but it also enables her to continue to be that rogue of her own volition. Miss Havisham defies conventions of how a rich female character ought to present herself since her run-down exterior hints at a grandeur that is of the past.

In the $2011 \mathrm{BBC}$ adaptation, Miss Havisham is portrayed by actor Gillian Anderson and the character starts out as a slightly odd, yet attractive middle-aged woman who is presented with perfectly formed curls in her crisp wedding dress. In the course of the three episodes, her gradual mental and physical demise is communicated to the audience by the rapid unravelling of her once carefully looked after hair, leaving it in a state of complete disarray. 
The connection between the condition of a woman's hair and virtuousness is, of course, an old one. Karen Stevenson notes that a woman's hair has always been associated with femininity and feminine beauty, and has also been regarded as a sign of virtue, especially as public marker to distinguish a woman from a man, and more importantly, from other less virtuous women such as witches who were usually depicted with wild und unkempt hair (140). The causality between Miss Havisham's messy looks and her rogue behaviour is also reflected in her equally disordered surroundings covered in dust where money seems to be scattered in dirty envelopes around her house, subtly hinting at her assumed financial inaptitude. Crucially, in the BBC adaptation Miss Havisham commits suicide by setting herself on fire while the 2012 adaptation with Helena Bonham Carter presents a much more vulnerable version of Miss Havisham who is desperately begging for Pip's forgiveness when her dress accidentally catches fire and the viewer is presented with a close-up of her burnt and disfigured body echoing Dickens's novel that also saw her stripped of her last wish to have her body displayed with dignity.

Fire also plays a central role in The Hundred and One Dalmatians in which Cruella de Vil holds an intense fascination for fire which is used to introduce her early on as a woman with abnormal desires: "Make it blaze for me," she instructs her husband and screams "[l]ovely, lovely" while "clapping her hands with delight" (Smith 14). Dodie Smith's novel intended for a young audience was first published in 1956 and then very successfully adapted by Disney in 1961, bringing about Smith's almost complete erasure as the creator of the popular children's story, which is also reflected in the fact that the first scholarly article concerned with her novel was only published in 2018. ${ }^{3}$ Her famous creation of Cruella de Vil, an extremely wealthy woman with a love of fur and a disdain for the animals that provide it, has since become a Disney icon who has served as a model for many female villains. The Hundred and One Dalmatians follows the lives of Mr and Mrs Dearly, their two Dalmatians and Cruella de Vil who wants to skin the Dalmatians' puppies and have their fur made into a coat. After the Dearlys refuse to sell the puppies, Cruella hatches a plan to have the dogs kidnapped and after a tumultuous search, they are safely returned to their rightful owners leaving Cruella ridiculed and in voluntary exile. The book and its two most famous Disney adaptations, the 1961 animation and 1996 live-action remake, demonstrate both a regression and an evolution in the portrayal of a rich female villain.

3 See Timothy C. Baker's “Oh, my dog owns me': Interspecies Companionship in Dodie Smith and Diana Wynne Jones." The Lion and the Unicorn 41.3 (2017): 344-360 (article became available in 2018). 
While generally very little information is revealed about Cruella de Vil's past and personal circumstances, the reader does discover that her rogue behaviour can be traced back to her childhood when she was expelled from school for drinking black ink and that she once had wealthy ancestors. The focus on her insubordination and her disregard for societal norms remains a central concern throughout the narrative and is demonstrated when she is first introduced disrupting the narrative when its "peace [is] shattered by an extremely strident motor horn" and a loud and "showy" woman emerges (Smith 8). The narrative heavily relies on simplistic binary descriptions of the characters as they are narrated to the reader through the eyes of the male Dalmatian Pongo who embodies the masculinist voice throughout the children's tale. I argue that one can read the choice to use Pongo's phallogocentric viewpoint as a tool to lay open some of underlying misogynistic undertones of the 1950s. In The Hundred and One Dalmatians this becomes especially apparent in the representation of rich individuals when the hypocrisy of the gendered description of wealth is revealed right at the beginning:

Mr Dearly, who had an office in the City, was particularly good at arithmetic. Many people called him a wizard of finance-which is not the same thing as wizard of magic, though sometimes fairly similar. At the time when the story starts he was rather unusually rich for a rather unusual reason. He had done the Government a great service (something to do with getting rid of the national debt) and, as a reward, had been let off his income tax for life. Also the Government had lent him a small house on the Outer Circle of Regent's Park-just the right house for a man with a wife and dogs. (Smith 4)

Mr Dearly's "unusual" richness is not mentioned thereafter in the book, while we never learn of Cruella de Vil's source of wealth or her income, leaving an air of suspicious mystery. The supposed contrast between the two sets of characters is further emphasized by a simplistic binary description putting Mr and Mrs Dearly and Cruella and Mr de Vil at diametrically opposing ends: the former live in a "small house" (Smith 4) whereas Cruella owns "a big house [Hell Hall]" (Smith 8). In the two Disney film adaptions, this contrast between the characters is further heightened by Mr Dearly's, then called Roger Radcliffe, occupation as an impoverished musician and video game animator resulting in a mode of narration that seeks to single out Cruella de Vil as even more cruel, ruthless and corrupted by money. Along with the same gendered stereotypes, the narrator seeks to further highlight Cruella's unruly character by presenting Mrs Dearly as the anti-rogue, the prototype of the ideal woman: "very pretty" (Smith 6) and "very truthful" (Smith 10). Cruella's apparent 
physical shortcomings and lavish presentation become a defining force in how she is perceived by those around her who assess her from head to toe:

\begin{abstract}
She was wearing a tight-fitting emerald satin dress, several ropes of rubies, and an absolutely simple white mink cloak, which reached to the high heels of her ruby-red shoes. She had dark skin, black eyes with a tinge of red in them, and a very pointed nose. Her hair was parted severely down the middle and one half of it was black and the other white-rather unusual. (Smith 8)
\end{abstract}

Cruella's "unusual" appearance is noted time and again in the narrative as a way to underline her "showy" character. Her confidence in her own appearance is a sign of the freedom and power her richness can offer her since she could not care less what those around her think of possessions she proudly shows off at every opportunity. Even more striking, however, is Cruella's hair which is parted in the middle and half black and half white emblematic of the black-and-white behaviour of women presented in the narrative which leaves very little room for them to occupy positions of ambiguity. Even though Cruella is clearly painted as the rogue of the story, she is given a much more vibrant personality, whereas the reader learns very little about Mrs Dearly who is consistently only mentioned by her married name and only ever seems to make an appearance with her husband. Cruella, in contrast, when asked by Mrs Dearly about her married name informs her that "[her] name is still de Vil" since "[she is] the last of [her] family so [she] made [her] husband change his name to [hers]" (Smith 8). This proto-feminist stance in Smith's book version is removed in the two film versions in which Cruella's status as a rogue spinster declares her unfit for marriage. The theme of marriage and naming more generally is one of the overarching concerns in the original narrative. Cruella's wealth grants her the freedom to name herself and others, clearly establishing her dominance which becomes even more palpable when it is implied that she had only married her husband, who "was a small, worried-looking man who didn't seem to be anything besides a furrier" (Smith 9), for his professional skills. This imbalance in gendered power makes Mr Dearly, who "isn't exactly handsome" himself (Smith 8), highly uncomfortable, repeatedly expressing his sorrow for Mr de Vil (Smith 11), a sentiment that is echoed by two cats at the end of the narrative who "feel quite sorry for him" but eventually come to the conclusion that the only difference between him and his wife is that "she's strong and bad and he's weak and bad" (Smith 176).

Smith's narrative's often ironically deployed sexist undertones become an extreme and regressive reality in the 1961 Disney animation One Hundred and One Dalmatians in which women, rather crudely, are 
likened to dog breeds and seem to come in three categories: too short, too old, and too young. Cruella has lost her distinguishing jewellery, as well as her husband, portraying her as the ultimate spinster gone rogue. The misogyny reaches its climax when Mr Dearly, now an impoverished musician called Roger Radcliffe, breaks into song declaring that Cruella de Vil is "an inhuman beast who ought to be locked up and never released," presenting a simplistic reading of Smith's much more nuanced description and laying open the male protagonist's misogynistic desire for a madwoman in the attic storyline. Pushing against the outdated gender stereotypes of the 1961 animation, the 1996 live-action movie 101 Dalmatians starring Glenn Close continues the storyline of the unmarried spinster but presents Cruella De Vil as the successful head of a global fashion empire, making explicitly visible for the first time the character's source of income and rebranding her as a self-made business woman.

"A rogue is a woman who challenges assumptions," Kirsten Backstrom reminds us, returning to her positioning of unruly women, which certainly holds true for Lady Tremaine, Miss Havisham, and Cruella de Vil. Their depictions are mediated by multiple male narrative voices and, as Backstrom points out, "when men determine the standard ... any independent woman is a rogue" (qtd. in Overall 54). Money and its circulation make hypervisible the patriarchal structures operating in the accumulation of assets and the power attached to it. Women still only own a small fraction of the enormous funds possessed by the richest individuals; in 2016, there were ten times as many male billionaires as there were female ones, and within those ten percent only 6 percent, 33 women, had actually made their own fortune $(\mathrm{S} \operatorname{cott})$. The scarce depictions of wealthy women in literature and film seem to be relegated to genres that allow readers to imagine the unimaginable. Much like the retellings of "Cinderella" as a fairy tale at the hands of Charles Perrault and the Grimm Brothers in which the evil stepmother is pitted against obedient Cinderella and the Fairy Godmother, insinuating the stepmother's witch-like qualities, The Hundred and One Dalmatians features supernatural elements such as the speaking animals, and Great Expectations displays "ahistorical fairly tale motifs" (Walsh 74) reflected in Miss Havisham's villainous portrayal alongside her decaying body. Embedding these rich rogues in fairy tales, stories aimed at children, or in semi-magical environments, effectively undermines women's rightful claim to wealth. The negative exceptionalism that is attributed to these rich women further extends to the "Fictional 15 " by Forbes magazine, in which we encounter rich women as caricatures in video games and animated films, high-functioning and emotionally disconnected alcoholics, sociopathic and violent criminals and eccentric spinsters. Nevertheless, the three rich rogues discussed in this article exhibit a hopeful display of proto-feminist 
tendencies relative to their historical context, a freedom that money can buy: Lady Tremaine gets to forcefully head her own household, Miss Havisham can afford not to remarry and sustain her withdrawn lifestyle, and Cruella de Vil has the financial means to seek voluntary exile in a "warm climate" (Smith 180) and continue to be "busy peppering her fruit salad" (Smith 16).

\section{Works CiTED}

101 Dalmatians. Dir. Stephen Herek. Perf. Glenn Close, Jeff Daniels. Walt Disney Pictures, 1996. Film.

Byrne, Eleanore, and Martin McQuillan. Introduction. Deconstructing Disney. Ed. Eleanore Byrne and Martin McQuillan. London: Pluto, 1999. 1-19. Print.

Cinderella. Dir. Clyde Geronimi, Wildfred Jackson and Hamilton Luske. Walt Disney Pictures, 1950. Film.

Cinderella. Dir. Kenneth Branagh. Perf. Cate Blanchett, Lily James. Walt Disney Pictures, 2015. Film.

Ciugureanu, Adina. "The Victim-Aggressor Duality in Great Expectations." Partial Answers 9.2 (2011): 347-61. Print.

Cullen, Bonnie. "For Whom the Show Fits: Cinderella in the Hands of Victorian Illustrators and Writers." The Lion and the Unicorn 27 (2003): 57-82. Print.

Dickens, Charles. Great Expectations. Oxford: Oxford World's Classics, 2008. Print.

Dolan, Kerry A., and Louisa Kroll. "Billionaires 2019.” Forbes.com. Forbes Magazine 5 Mar. 2019. Web. 30 May 2019.

Ewalt, David M. "The 2013 Forbes Fictional 15" Forbes.com. Forbes Magazine 16 Jun. 2014. Web. 20 Feb. 2018.

Great Expectations. Dir. Brian Kirk. Perf. Gillian Anderson, Vanessa Kirby. BBC One, 2011. Film.

Great Expectations. Dir. Mike Newell. Perf. Helena Bonham Carter, Jeremy Irvine. BBC Films, 2012. Film.

Grimm Brothers. The Complete First Edition: The Original Folk E Fairy Tales of the Brothers Grimm. Trans. and ed. Jack Zipes. New Jersey: Princeton UP, 2014. Print.

Hall, Donald E. Fixing Patriarchy: Feminism and Mid-Victorian Male Novelists. Basingstoke: Palgrave Macmillan, 1996. Print.

Hartog, Curt. "The Rape of Miss Havisham." Studies in the Novel 14.3 (1982): 248-65. Print.

Howard, Carol. "Why Are There So Few Rich Fictional Women?" Forbes. com. Forbes Magazine 6 Apr. 2011. Web. 20 Feb. 2018. 
Levine, Caroline. "Realism as Self-Forgetfulness: Gender, Ethics, and Great Expectations." Bloom's Modern Critical Interpretations: Charles Dickens's "Great Expectations." Ed. Harold Bloom. New York: Blooms Literary Criticism, 2000. 99-113. Print.

Lin Chang, Mariko. Shortchanged: Why Women Have Less Wealth and What Can Be Done About It. Oxford: Oxford UP, 2010. Print.

Merkin, Daphne. "The Rich in Fiction." Newyorker.com. The New Yorker 12 Sept. 2015. Web. 20 Feb. 2018.

Noer, Michael. "Why So Few Women on the Forbes Fictional 15?" Forbes. com. Forbes Magazine 10 Mar. 2011. Web. 20 Feb. 2018.

One Hundred and One Dalmatians. Dir. Wolfgang Reitherman, Clyde Geronimi and Hamilton Luske. Walt Disney Pictures, 1961. Film.

Overall, Christine. A Feminist I: Reflections from Academia. Peterborough: Broadview, 1998. Print.

Perrault, Charles. The Complete Fairy Tales by Charles Perrault. Trans. Christopher Betts. Oxford: Oxford UP, 2009. Print.

Putnam, Amanda. "Mean Ladies: Transgendered Villains in Disney Films." Diversity in Disney Films: Critical Essays on Race, Ethnicity, Gender, Sexuality and Disability. Ed. Johnson Cheu. Jefferson: McFarland, 2013. 147-62. Print.

Scott, Bartie. "The Richest Self-Made Women In The World 2016.” Forbes. com. Forbes 2 Mar. 2016. Web. 20 Feb. 2018.

Smith, Dodie. The Hundred and One Dalmatians. London: Puffin, 2002. Print. Stevenson, Karen. "Hairy Business: Organising the Gendered Self." Contested Bodies. Ed. Ruth Holliday and John Hassard. London: Routledge, 2001. 137-52. Print.

Thornton, Sara. "The Burning of Miss Havisham: Dickens, Fire and the 'Fire Baptism." Bloom's Modern Critical Interpretations: Charles Dickens's "Great Expectations." Ed. Harold Bloom. New York: Blooms Literary Criticism, 2000. 79-98. Print.

Walsh, Susan. "Bodies of Capital: Great Expectations and the Climacteric Economy.” Victorian Studies (1993): 73-98. Print.

\section{Veronika Schuchter is currently OeAD-Lektorin} (Austrian Academic Exchange Lecturer) at the University of Oxford. Her doctoral project investigates supermodern spaces in contemporary British and Canadian women's writing. She is particularly interested in feminist and postcolonial theory and all aspects of women's writing. She is part of the executive committees of the Contemporary Women's Writing Association (CWWA) and the Feminist and Women's Studies Association (FWSA). 